Quarterly Review of Film and Video

ISSN: 1050-9208 (Print) 1543-5326 (Online) Journal homepage: https://www.tandfonline.com/loi/gqrf20

\title{
Zéro de conduite: Jeunes diables au collège (Zero for Conduct)
}

\section{Maria Pramaggiore}

To cite this article: Maria Pramaggiore (2010) Zéro de conduite: Jeunes diables au collège (Zero for Conduct), Quarterly Review of Film and Video, 27:5, 413-415, DOI: 10.1080/10509208.2010.495003

To link to this article: https://doi.org/10.1080/10509208.2010.495003

曲 Published online: 04 Oct 2010.

Submit your article to this journal

Џلll Article views: 170 
the film has remained to this day, as contemporary German cinema is still awaiting a more systemic effort at rejuvenating what constitutes the lifeblood of any properly functioning film industry: genre cinema.

Marco Abel teaches film studies and continental theory in the Department of English at the University of Nebraska and is currently working on his second book, The Berlin School: Toward a Minor Cinema. He has a longer essay on Dominik Graf forthcoming in Generic Histories: Genre and its Deviations in German Cinema (ed. Jaimey Fisher).

\title{
Zéro de conduite: Jeunes diables au collège (Zero for Conduct)
}

\author{
MARIA PRAMAGGIORE
}

Refused a certificate by the French Comité national du cinéma (Film Control Board) on the grounds that its satirical attack on the education system was seditious, Jean Vigo's Zéro de Conduite (1933) would not be screened commercially in France until 1945, 11 years after the director's death from tuberculosis at age 29. Although the film had not been widely seen between 1933 and 1945, it had been so frequently discussed that a number of French critics were disappointed in its post-war resurrection, finding Vigo's ethereal treatment of schoolboy subversion less explosive than they anticipated and complaining that the film's experimental techniques were somewhat passé.

Eventually, Vigo's small body of work would earn recognition as a precursor to poetic realism and the Nouvelle Vague. The prestigious Prix Jean Vigo would be awarded to independent filmmakers including Alain Resnais, Jean-Luc Godard, Ousmane Sembène, and Noémie Lvovsky. Zéro de conduite would be quoted by François Truffaut and Lindsay Anderson, Louis Malle, Peter Weir, and Wes Anderson. On a more prosaic level, Animal House (John Landis, 1978), The Breakfast Club (John Hughes, 1985), and even the Harry Potter films could not have existed without Vigo's pubescent pathbreakers.

There is a strong argument to be made that, on the basis of its historical significance alone, Vigo's paean to artful dissidence at a boys' boarding school ought to be made available to film enthusiasts and youthful rebels everywhere. Boris Kaufman, who shot all of Vigo's films, was Dziga Vertov's brother and learned how to use a camera through what we now call distance education, exchanging letters with his brother Mikhail, who shot Man With a Movie Camera (Dziga Vertov, 1929). Vigo's opening train ride sequence possesses a rhythmic choreography that, like Vertov's film, situates tenderhearted humans within the industrial age.

Maurice Jaubert scored the film, freely exploring sound as an uncanny rather than a realistic element. At times, a chorus of boy's voices intrudes into the soundtrack without any anchoring image. Jaubert took particular care with the composition that accompanies a midnight pillow fight among the boys that morphs into a triumphant march in slow motion. He instructed the musicians to play the notes in reverse order and then he reversed the recording on the final soundtrack, anticipating by a decade the kind of experimentation associated with musique concrete. With a text this saturated with film history, it's frustrating 
to note that, at the time of this writing, Zéro de conduite is available only on a Region 2 DVD collection released by Artificial Eye.

The film's pedigree, although impressive, is not the reason that Vigo's merry pranksters leave such an indelible mark, or why it ought to be required viewing on college campuses. In the spirit of Caussat, Colin, Bruel and, most of all, Rene Tabard-Vigo's ragtag, fledgling French resistance-I demand the immediate release of Zéro de conduite in Region 1 because it's a marvelous depiction and enactment, of liberating, collective acts of creativity under duress.

Vigo was known for his belief in a "social cinema" that demanded the filmmaker take a position. This social vision is evident throughout Zéro de conduite, not only in terms of its story and style, but also its mode of production, which in many ways anticipated Italian Neorealism. Vigo spotted his young ruffians, the centerpiece of the film, on the street, followed them home, and asked their parents for their cooperation. The film's instructors and headmasters were mostly friends and acquaintances of Vigo's. The action was improvised to such an extent that some who worked on the production worried about the increasingly boisterous behavior of Vigo's pack of lads.

Simply put, this film is a natural for the college classroom. As a short film, it's a genre that is all too often overlooked outside courses on early film history. Vigo and Kaufman's surreal documentary style offers an alternative to the conventions of narrative cinema as well as the strict categories of fiction, documentary and avant-garde cinemas that students are all too familiar with.

Finally, the film demands to be viewed in the context of educational practices because of what it has to say about institutional culture. Vigo's structured, yet dream-like narrative introduces us to teachers, headmasters, and principals who, with one exception, wield the threat of "zero for conduct," yet have little interest in imparting any wisdom or fostering student learning. One steals chocolate from students; another unctuous blowhard, Monsieur Viot, is suspiciously solicitous of Rene Tabard, and caresses his hand. The school authorities, seemingly blind to Viot's predatory behavior, instead label the friendship between the boys Bruel and Tabard "unwholesome." The Principal counsels Tabard, expressing, though hardly articulating, his fear of the love that dare not speak its name: "neuropaths, psychopaths ... and who knows what else!"

The hirsute Principal's diminutive stature visually suggests an overturning of hierarchies and foreshadows the students' ultimate triumph in the final scene, where they pelt the dignitaries and (literal) dummies with garbage from the rooftop on the school's Commemoration Day. The jokes that attend this small man might seem juvenile and gratuitous elsewhere, but in a film concerning the authoritarian stewardship of ungovernable youngsters, the sheer absurdity of a pompous, grown man smaller than the unruly children giving the orders evokes laughter and a sublime visual poetry.

The kids, happily, take care of one another, as kids usually do. Tabard has a hiding place for the boys' stash of chocolate, and the co-conspirators stop the food fight when it upsets Colin, whose mother is consigned by the school's stingy patriarchs to serve beans every night. The boys are pranksters who perform tricks for their schoolmates (using the special effects of Méliès), but play tricks on their elders throughout, saving the piece de resistance for the pretentious Commemoration Day.

Most of all, incipient revolutionary Rene Tabard ought to be given his due within the context of Queer film studies. Tabard is not only a courageous rebel; he also has the temerity to wear his academic gown like a Grecian tunic: on him, it's chic. He slings his Garbo-esque bob around as he throws the corruption of his elders back into their faces. "To you, sir, I say: shit," Tabard proclaims, when the miniature Principal asks him to apologize 
to his pedophile admirer. I'm inclined to say the same to distributors who have failed to grasp the critical importance of Vigo's film not only to cinema's history and aesthetics but also to its ethics.

Maria Pramaggiore is a Professor of Film Studies at North Carolina State University. She is the author of Neil Jordan (University of Illinois Press, 2008) and Identifying Others and Performing Identities: Irish and African American Cinema, 1980-2000 (SUNY Press, 2007) and the co-author with Tom Wallis of Film: A Critical Introduction, 2nd edition (Laurence King Publishers and Pearson, 2007)

\title{
Where the Lilies Bloom
}

\author{
MARK A. HAIN
}

The 1970s are often regarded as the era in which American cinema "grew up." Many of the most notable films of the decade, distinguished by an increased complexity both conceptual and formal, darker themes, and an overall move to film as an expressive yet analytical art, appeared to address a sophisticated, urban, perhaps left-leaning adult audience. What remains little examined, however, is the influence of this "New American Cinema" on children's and family films. Where the Lilies Bloom, William A. Graham's poignant yet starkly unsentimental 1974 family film set in current-day Southern Appalachia, advantageously picks up several characteristics of New American Cinema, but while it deals with more troubling matters than most films for young people, is free of the cynicism of many adult films of the era. It is also a film distinctive in its simplicity and sincerity, and deserving of wider recognition.

If, as numerous film scholars have argued, the overt influence of "difficult" European art cinema on New American Cinema implies certain ideological leanings, then it is arguably all the more important to consider what these films may communicate to young audiences. The most apparent, and celebrated, example of New American Cinema's influence on family films is Martin Ritt's Sounder (1972), which in its somber tone and unsparing depiction of deprivation, racism, and injustice represents a seismic shift from its undemanding family film forebears; it is a film that challenges its young audience rather than just entertains.

Although less acclaimed, Where the Lilies Bloom, based on the1969 young adult novel by Bill and Vera Cleaver, is comparably weighty, moving, and ultimately uplifting in telling the story of the Luther family, four orphaned children determined to stay together by concealing their father's death. Like Sounder, it makes troubling social issues relatable to young audiences without equivocating or patronizing, seeming to say, "you're old enough and smart enough to handle this." Unlike Sounder, however, in which the evil of racism is easily embodied in readily identifiable villains representative of oppressive social systems, Where the Lilies Bloom tackles less palpable issues of class and regional bias in confronting the realities of Southern rural poverty. The film humanizes characters who might be dismissed as "white trash," but renders the power systems that keep them poor and afraid as faceless "institutions," vague thus unaccountable.

Similarities between Where the Lilies Bloom and Sounder go beyond challenging subject matter and gritty realism: advertising for Where the Lilies Bloom touted that it had 